ECONOMICS

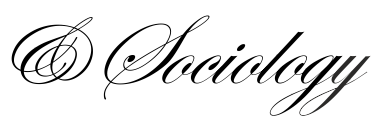

Viktor Koziuk, Ternopil National Economic University, Ternopil, Ukraine E-mail:

viktorkoziuk@tneu.edu.ua

Oleksandr Dluhopolskyi, Ternopil National Economic University, Ternopil, Ukraine E-mail:

dlugopolsky77@gmail.com

\begin{abstract}
Antonina Farion, Ternopil National Economic University, Ternopil, Ukraine E-mail:a.farion@tneu.edu.ua
\end{abstract}

Tetiana Dluhopolska, Ternopil National Economic University, Ternopil, Ukraine E-mail: tetianadluhopolska@gmail.com

Received: October, 2017

1st Revision: Febraury, 2018

Accepted: May, 2018

DOI: 10.14254/2071-

789X.2018/11-3/7

JEL Classification: A13, H14, I31, P50
Koziuk, V., Dluhopolskyi, O., Farion, A., \& Dluhopolska, T. (2018). Crony Sectors as a Barrier to Economic Well-Being and Ecologization (Case of Ukraine). Economics and Sociology, 11(3), 113-132. doi:10.14254/2071-

789X.2018/11-3/7

\section{CRONY SECTORS AS A BARRIER TO ECONOMIC WELL-BEING AND ECOLOGIZATION (CASE OF UKRAINE)}

\begin{abstract}
This paper investigates the relationship between oligarchic economies and the crony sector development, which includes industries with the dominating rent-seeking behavior. In order to analyze the period from 2006 till 2016, cross-countries' data on the Power Distance Index, Crony Capitalism Index, Sustainable Society Index, among with the environmentally related taxes are referenced. Regression analysis for the distance to power and dependence on crony capitalism is carried out with a focus on the relation between crony capitalism and ecologization. Existence of a vicious cycle associated with hierarchical tolerance and barriers towards ecologization in modern welfare economics, is debated. Conclusions are made concerning the cultural and social factors having their direct impact on the existence of crony sectors and functioning of weak institutions
\end{abstract}

Keywords: oligarchy, crony-sectors, ecologization, institutions, well-being, environmental taxes.

\title{
Introduction
}

Domestic Ukrainian scientific circles are increasingly discussing the possibility of ensuring welfare within society through the economic systems affected by the phenomenon of usurpation of power, neo-pseudo-corruption and rent-seeking behavior of economic agents. These features are typical of an oligarchic societies (including Ukraine). The very term "crony 
capitalism" is understood as a capitalist economy in which business success depends on personal relationships between businesspersons and government officials (Kang, 2002). Such connections are actively used in developing economies to obtain licenses, subsidies, and state orders on beneficial terms, violating formal and informal rules. Originally, the concept of crony capitalism was applied to the economy of the "Asian tigers" in the 1960-1990s, in which business interests were closely intertwined with the party (Volhonsky, 2008; Pei, 2016), but crony capitalism today is becoming especially widely spread in the economies of the post-soviet countries (Helman, 2010; Zingales, 2012).

In general, the processes of overcoming practices of corruption and minimizing the impact of crony capitalism is the focus of institutions that are called to eliminate manifestations of opportunistic behavior of subjects, regardless of their political, social, or economic status in the society. On the other hand, the ability of society to build effective institutions so that to prevent the spread of oligarchic structures largely depends on the attitude towards power and the propensity to hierarchy. It can be assumed that the greater is the tolerance of hierarchical relations within a level of culture, the less will the society oppose those forms of economic processes and the formation of institutions that can be preserved by oligarchism (Kozyuk, \& Dluhopolskyi, 2017). This does not mean, howeer, that the distance of power is always a negative phenomenon, especially when it comes to subordination and labor ethics. This article is devoted to the study of the hypothesis that competitive pressure is an important prerequisite for the formation of market constraints for the transformation of hierarchical modalities of behavior into oligarchic structures, which paralyze welfare development and ecologization of the economy.

The theoretical approach of ecologization is based on two hypotheses. According to the Environmental Kuznets curve hypothesis (Kuznets, 1955), environmental impacts tend to increase initially as a country becomes richer, but then eventually decrease with further increase of income. This approach suggests there is a relationship between income and environmental impacts in an inverted-U shape. Another well-known hypothesis is the Porter hypothesis (Porter, 1995) which argues that environmental regulation can lead to lower costs for firms. The Porter approach notes that firms may not be focused on the ways to reduce environmental impacts, thus missing the potential cost-saving innovations. Regulations may make firms more aware of new technologies and direct investments in new areas of research. The Porter hypothesis has been empirically tested by comparisons at both firms' and nations' levels (Porter, 1995; Wagner, 2003).

This article is dedicated to the analysis of the crony sector's role in the development of well-being and ecologization. After the introduction, section 1 provides a literature review on oligarchization and crony capitalism development. Next, section 2 describes the methodological approaches applied in this article. Section 3 describes the role of add quotation marks to this term, because it is not yet defined in economic development. Further, section 4 is devoted to oligarchical economic development and its impact on ecologization. Finally, the last part presents conclusion and recommendations of the article.

\section{Literature review}

The dependence of the socioeconomic development of countries around the world on the excellence of their institutions has become the subject of extensive scientific discourse at the beginning of the twenty-first century. D. North, J. Wallis and B. Weingast's work (North, Wallis, \& Weingast, 2009) appeals to the importance of constructing "open access" for institutions, in order to prevent corruption and nepotism, but to form a qualitative environment 
that nourishes democracy, as opposed to "closed access" societies, with authoritarianism, oligarchism and rent-seeking behavior of economic agents.

Works devoted to the institutional development of Latin American countries (Sorj, \& Martuccelli, 2014; de Soto, 2017) reveal the main causes of the emergence of clan-capitalism in these economies - a discriminatory system of property rights and inability to generate capital. D. Acemoglu and J. Robinson $(2015 ; 2016)$ study and contrast the oligarchic and democratic models of development in details (Acemoglu, 2008). They describe the experience of Japan, South Korea, Brazil, and Mexico as states that once had or still have retained the hallmarks of an oligarchic society. Large family conglomerates with close ties to the politicians were spread in the post-war period (second half of the XX century) both in Korea («chaebol») and in Japan («zaibatsu»). Such companies actively used subsidies and soft loans, and the government protected not only their property rights but also domestic markets from foreign competition (Evans, 1995). Examples of Brazil and Mexico at the beginning of the XX century, as described by S. Haber (Haber, 2003), allow us to trace the influence of the lobbying of large corporations on the executive branch of government. In multi-party presidential systems in Latin America, it is difficult for the president to form effective legislative coalitions without the support of the oligarchs, hence he must take actions or risk being removed from office (as exemplified in Paraguay and Venezuela) (Lopes Harsia, 2017).

In general, oligarchic economies often show rapid growth at the beginning of the oligarchs' entry into power, but over time undergo necessary stagnation due to the tendency of producing poor-quality institutions. Similarly, oligarchies with formally democratic regimes can have rapid economic growth, but will be vulnerable to the low quality of institutions and, ultimately, allotment efficiency. As a rule, they will grow due to factors of raw material and global prices. In contrast, raw autocracies can support welfare improvements by monopolizing access to rent and controlling its distribution. The implicit impact of social contracts means that the conversion of raw material wealth into social welfare is "a payment for loyalty and compensation for the lack of democratic rights" (Kozyuk, 2014; 2016).

A. Aslund notes, when comparing the oligarchic economies of Russia and Ukraine, that there was no big difference in the regimes by B. Yeltsin and L. Kuchma (Aslund, 2005). It's importante to note that oligarchical power is based on money, to, where scientists call them plutocrats. In addition, the methods used by the post-soviet oligarchs to make their first capital slightly differ from the methods of the so-called "robber barons" (the oligarchs of the late XIX century in the United States), who acquired their wealth mainly through industries generating monopoly rent (oil mining and trading, metals trading, and railway transportation). But it's great thing T. Roosevelt acted as a "trust buster" who introduced regulatory reforms and antitrust prosecutions in the U.S. to promote competition, so the consumers of capitalism would have the power of decision. The question is: If this will ever happen in Ukraine or Russia? J. Hellman uses the term "state capture" in relation to the characteristics of the interaction between large business and public administration in countries like Ukraine (Hellman, 1998).

The studies of domestic economists V. Konchin and Y. Horban (2016) outline the problem of the economic point of bifurcation for the Ukrainian oligarchic state, where scientists use the "model of a stationary bandit" (McGuire, Olson, 1996). Using multi-factor regression models, it was established that the increase of the state debt by $1 \%$ of GDP causes a decline of $1,437 \%$, along with the deterioration of welfare of the citizens of the country. O. Soskin also researches the Ukrainian state in the context of the model of oligarchic-clan capitalism (Soskin, 2014), believing that the transition to a qualitatively new model is possible through integration into the European Economic Area and institutional progress. Democratic regimes and quality institutions are hampering the usurpation of power and rent-monopolization from oligarchs, even in commodity economies (Dluhopolskyi, 2015; Kozyuk, \& Shimanska, 2013; Kozyuk, 
2017), in which civil society has been formed (examples of Norway and Canada prove this). But for Ukraine, there are problems of informal institutions rather than formal, clientism and clans in all spheres of socio-economic activity and the weakness of "movements from below". One of the principal features of the oligarchic economy is an attempt to maximize assets as a factor of securing political power and as a source of its control (Kozyuk, \& Shimanska, 2013). Such maximization of assets and political control cannot be implemented without a significant stratification of society. The ability of the latter to accept the fact of inequality is not yet evidence of the tolerance of oligarchic structures. However, the factor of power distance and "indulgement to the hierarchies" is common. Because of this, there will be a risk that oligarchization will most likely arise where the cultural background in terms of power treatment is a contributing factor.

One of the biggest challenges for oligarchism is the ecologization of the economy. This modern trend changes the economy in different ways to increase human prosperity and to reduce environmental impact (Figure 1). The key schools of ecologization includes: 1) agricultural economics (green revolution in agriculture); 2) welfare economics (concept of wellbeing); 3) natural resource economics (scarcity of resources and resource curse concepts); 4) energy economics (low-carbon policy); 5) environmental economics (concept of negative externalities); 6) ecological economics (sustainable development paradigm) (McCormick, Richter, \& Pantzar, 2015).

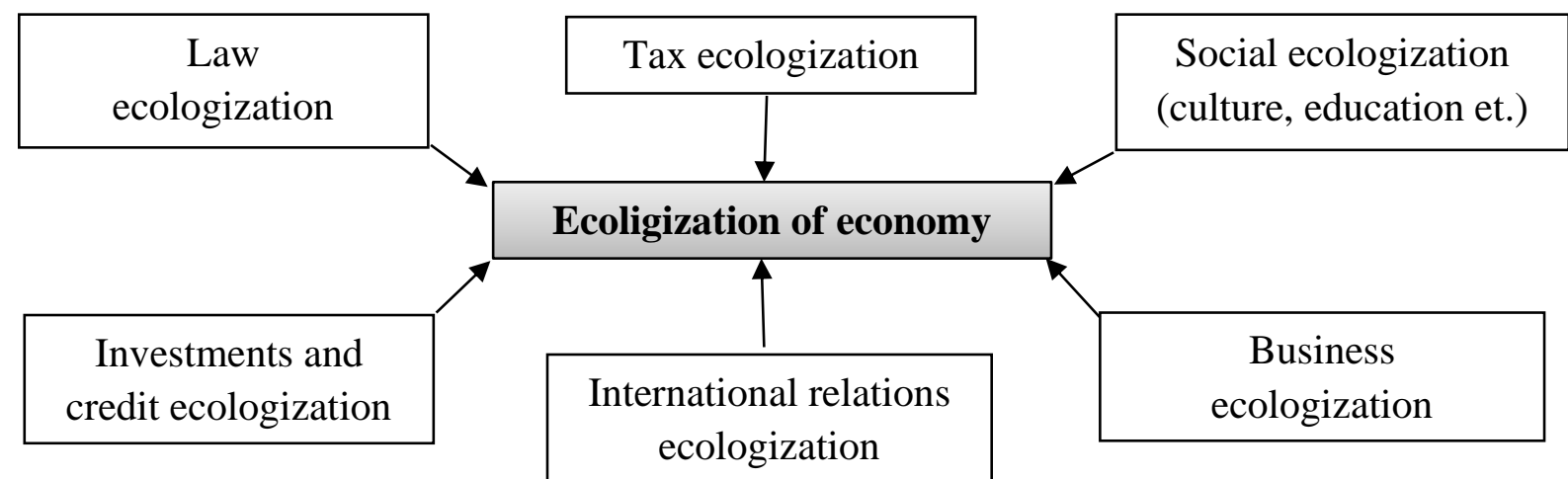

Figure 1. Main ways of ecologization

Source: compiled by authors

The definition of "ecologization" as a result of the conversion of the term "ecology", was first used by the German naturalist E. Haeckel in 1866. Since then, long-lasting arguments about the environment - until the second half of XX century - led to conversations about "greening". The actual category of ecologization arose due to the fact that the notion of nature and its protection could no longer contribute to the need to protect the entire biosphere (Kharlamova, 2015). Ecologization essence can be defined as implementation of an ecological approach to people's lives, which is conducive to the formation of a new worldview, according to which humans must evaluate their activities to how actions are harmonized with the laws of nature. According to UNEP (United Nations Environment Program, 2011), a green economy is an economy which results in improved human well-being and social equity, while significantly reducing environmental risks and ecological scarcities. In its simplest expression, a green economy can be thought of as one which is low carbon, resource efficient and socially inclusive. The ecologization of an economy foresees the realization of the system of special organizational measures, innovative processes, the reconstruction of production and service spheres, modification of consumer demand, the technological conversion, the rationalization of natural 
management, and also the transformation of nature protection activity. But most of these activities don't correspond with the aims of an oligarchy, and that's why agents from rentseeking sectors try to stop the progress of ecologization. The aim for undertaking this article is to develop our previous research about the power distance and crony capitalism relationship in developed and developing economies (Kozyuk, \& Dluhopolskyi, 2017), and to analyze the level of influence of crony-capitalism on ecologization indicators worldwide.

\section{Methodological approach}

The objective of the article is to analyze the influence of crony-capitalism on the indicators of ecologization in both developed and developing economies. In this context, the question of a society's welfare ensured under the conditions of an oligarchy and a highly corrupt economy arises, as well as what economic policy should be, taking into account the existence of a favorable cultural environment for the development of oligarchic-hierarchical interactions, which are very often against innovations, greening and overall well-being.

To accomplish this objective, the following scientific methods are used: intuitive searches, regression analysis, and comprehensive analysis. In order to explain the connections between variables (Crony-capitalism index and Environmental Performance Index) we took indicators such as the share of sectors with domination of rent-seeking behavior as a percent of the GDP controlled by oligarchs in the crony-sectors (Our Crony-capitalism Index), along with the level of sub-indexes of the Environmental Performance Index (Environmental Performance Index) from 22 countries. Data was statistically analyzed in Excel.

\section{Role of power distance}

Typically, the impetus for the development of oligarchs is rooted in degenerative institutes. However, the oligarchs, having been able to establish themselves, begin to preserve institutional weaknesses. The main thing is that the conservation of weak institutions is a way of self-reliance. Poverty, along with corruption is a way of additional control over the citizens who tolerate the authorities' distances.

Thus, according to the data of the international organization Transparency International, Ukraine has improved its position in the Corruption Perceptions Index (CPI) by only 3 points - from 26 to 29 points since 2012, having taken 131st place among 176 countries of the world in 2016. Russia has improved its position in the CPI rating from 28 to 29 points, nevertheless sharing 131st place with Ukraine in 2016 (Corruption Perceptions Index, 2016). It is noted that $56 \%$ of Ukrainians and $39 \%$ of Russians consider corruption to be one of the key issues in the development of their national economies, and $86 \%$ and $62 \%$ correspondingly estimate all measures to combat it as ineffective (People and corruption, 2016). If we analyze the rating of bribes paid to police, education, health care, social protection, and judiciary employees, then Ukraine has a figure of 38\%, Russia 34\%, whereas in the Netherlands, France, and Portugal $2 \%$, and additionally, Belgium, Germany, Spain, and Slovenia - 3\%. In general, most countries of the former socialist camp are characterized by a high level of bribes (Tajikistan - 50\%, Moldova $-42 \%$, Kyrgyzstan, Azerbaijan - 38\%, Kazakhstan - 29\%, Armenia - 24\%, Belarus $-20 \%$, Uzbekistan - 18\%) The exception is Georgia with only $7 \%$.

The rigor of the system becomes evident due to the obvious signs of corruption behavior and its correlates - property stratification which often does not evoke explicit resistance from civil society. The fact that the corrupt-oligarchic system has been formed over the years is of course important, but the combination of compromises on structural reforms does not produce a tangible result for civil society. The lack of value incentives and the domination of rent- 
oriented practices among officials of different levels, and the focus on short, rather than longterm results of socio-political life is exacerbated by the weakness of civil society, which is incapable of confronting the total usurpation of power. We believe that one explanation for such a situation should be found in cross-cultural studies that link culture, institutions and socioeconomic development (in particular, the power distance).

The Power Distance Index (PDI) describes the rigidity of the social hierarchy of society and its impact on the interaction between people and the functioning of social institutions. In the 1970s this term was introduced by the Dutch sociologist G.Hofstede, on the basis of a largescale cross-cultural study conducted by him in 1967-1973 in more than 70 countries all over the world (Hofstede, 2001). In the 2000s, the study was continued and covered a total of 76 countries (Hofstede, Hofstede, \& Minkov, 2010). The scholar understood hierarchy as an uneven distribution of power and authority within social groups, and the PDI itself characterizes attitudes among members of society to this unevenness - how members of the society, deprived of power, accept the existing hierarchy and behave accordingly (Kozyuk, \& Dluhopolskyi, 2017).

The index proposed by G. Hofstede assigns a culture of a certain country a comparative number that characterizes the degree of distance in the interaction of people who are at different levels of the social hierarchy. The high index of the power distance (80-100) indicates the stiffness of the social structure with significant social inequality. Each person in such cultures has an appropriate place in the social hierarchy and the corresponding place of authority, and the fact that such hierarchy is taken by default, is beyond doubt and does not require additional substantiation (Power Distance Index). Table 1 demonstrates the main characteristics of societies with high and low level of PDI.

Table 1. Features of societies with high and low PDI

\begin{tabular}{ll}
\hline \multicolumn{1}{c}{ High level of PDI } & \multicolumn{1}{c}{ Low level of PDI } \\
\hline 1) centralized power; & 1) the liberal management style; \\
2) authoritarian leadership; & 2) equality of rights; \\
3) vertical management style; & 3) individual freedom; \\
4) a large number of levels in the social hierarchy; & 4) public control over the distribution of powers; \\
5) the adoption of the power privileges as inherent & 5) the requirement of justification for the unlawful \\
ones; & allocation of power; \\
6) readiness of members of society for inequality & 6) egalitarianism; \\
of powers; & 7) decentralization; \\
7) a large number of personnel with controlling & 8) the tendency to question the authority; \\
functions; & 9) advisory style of management; \\
8) low level of trust to the power institutions; & 10) the prevalence of "flat" organizational structures; \\
9) managerial paternalism; & 11) high level of trust (social capital); \\
10) confidence in the values of survival, & 12) the values of self-expression, et. \\
11) low and medium level of trust, et. & \\
\hline
\end{tabular}

Source: compiled by authors.

According to the data of the Figure 2, such societies include Malaysia, Slovakia (PDI = 100), Saudi Arabia (PDI = 95), Philippines (PDI = 94), Russia (PDI = 93), Ukraine (PDI = 92), Romania, Albania (PDI = 90) and many other countries. The GDP per capita in such countries is usually low (from 21.6 thousands in current US \$ in Slovenia in 2016, to 2.9 and 2.2 thousands in current US \$ in Philippines and Ukraine in 2016 (The World Bank, 2016). The only exception is Singapore, a country with inherited legislation from British colonial rule and a rigorous system of punishment for lawbreakers, and Saudi Arabia as a classical commodity economy in which the petroleum industry provides about $80 \%$ of the state budget revenues. 
Interestingly, even in India, with its highly centralized and caste society, the PDI value is significantly lower than in Ukraine, and in Slovakia it is higher. Since the culture of Ukraine is characterized by clientism, nepotism, and loyalty to corruption, where the practice of decisionmaking at different levels of government becomes the principle of "everything for friends, the law for enemies", and job placement is ruled by "the same homeland". Today's Ukraine slightly differs from many African countries where bribes must be paid for job placement or promotion - to be prepared for "kickbacks" and rent-oriented behavior in favor of the so-called "philanthropist", and to bypass corruption practices in the labor market, which are mainly possible through personal connections. All this leads to the inefficiency of public administration, blocking innovative initiatives from the bottom, preservation of the management structure, creation of inequality of opportunities and development of substandard institutions.

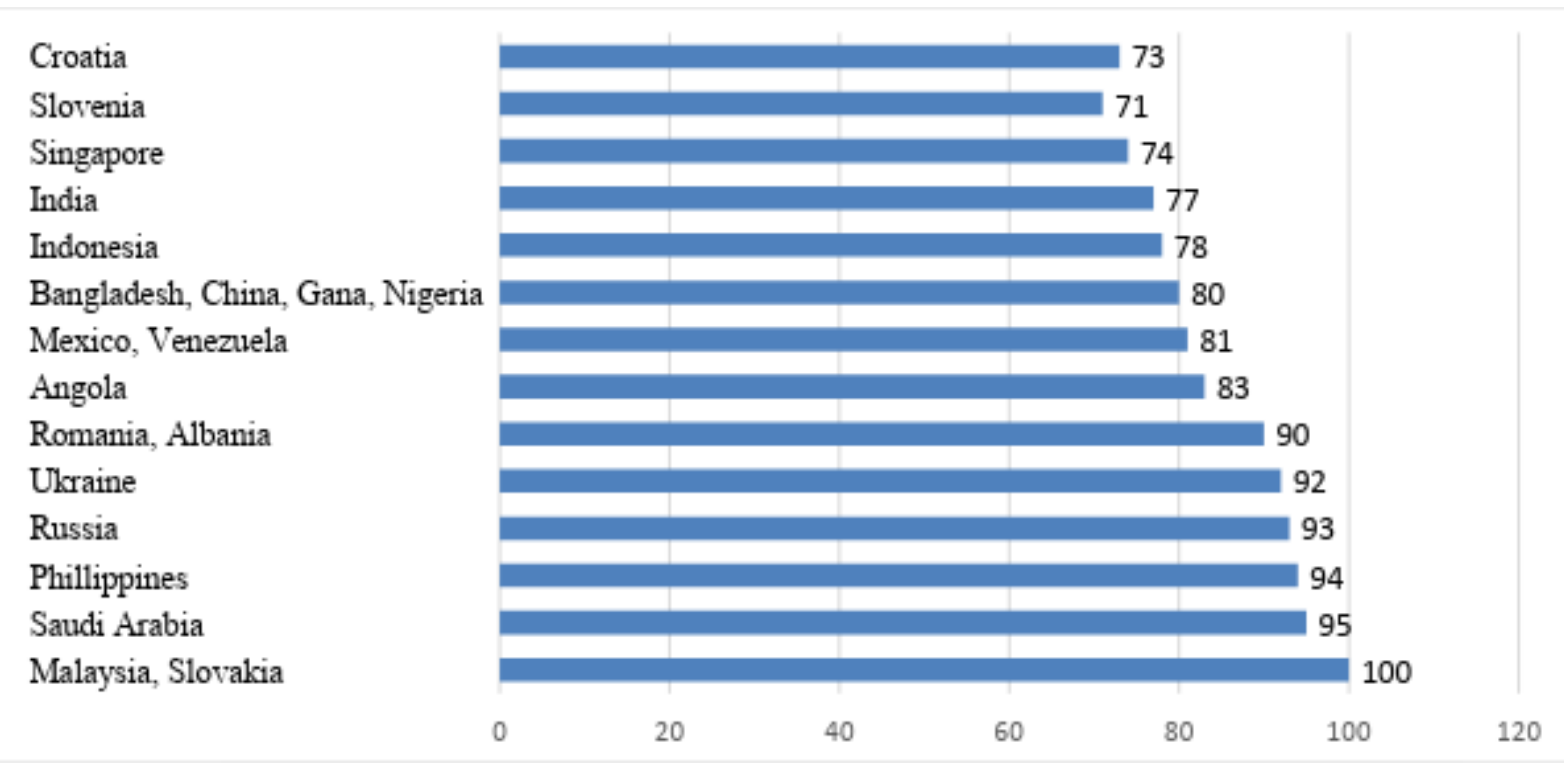

Figure 2. Examples of countries with high PDI

Source: compiled by authors based on (Power Distance Index).

The group of countries with an average PDI is rather heterogeneous. There is Bulgaria with PDI $=70$ and 7,4 thousands of GDP per capita in current US \$ in 2016, the value of human development index (HDI) is 0.782; Pakistan with PDI $=55$ and 1.4 thousands of GDP per capita in current US \$ in 2016 (The World Bank, 2016), the value of HDI - 0.538, as well as Japan with PDI $=54$ and 39 thousands of GDP per capita in current US \$, the value of HDI -0.891 (Figure 3). If countries such as Japan and South Korea in this group are characterized by respect for the hierarchy of governance, strict adherence to corporate traditions and strict compliance with the relationship "chief - subordinate", "senior - younger", then, for example, in Argentina, Brazil, and Colombia, the situation is fundamentally different both in public administration and in business. These countries are dominated by traditional values that dramatically differentiate them from Japan and South Korea with a pronounced rationalism. 


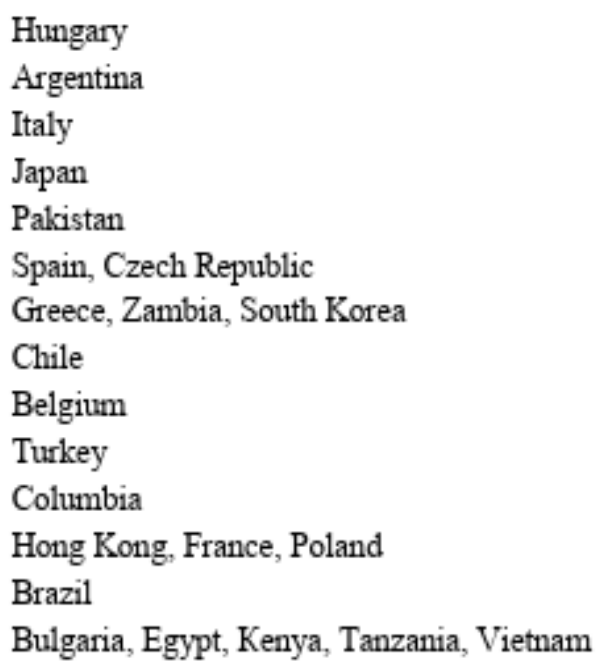

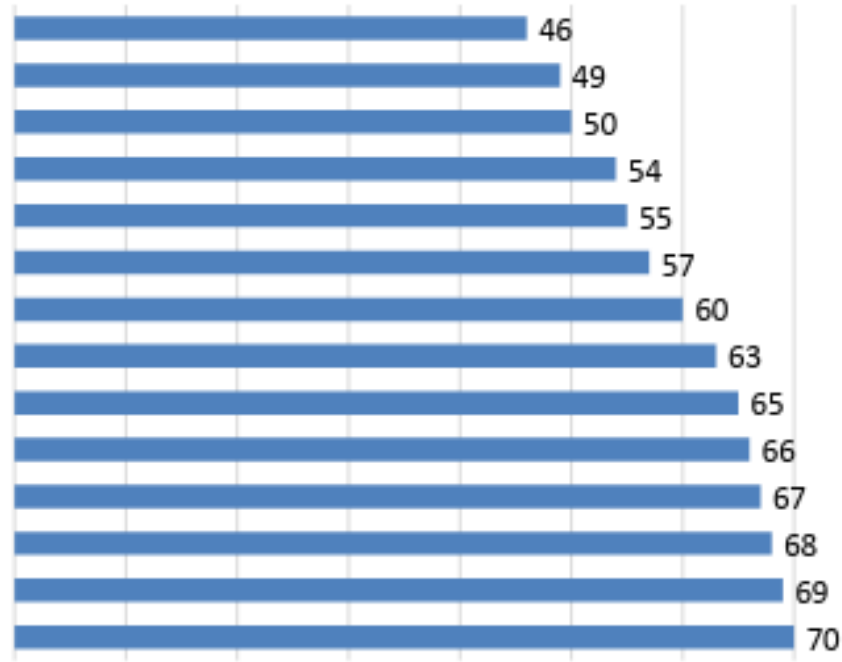

1020

30

40

Figure 3. Examples of countries with average PDI

Source: compiled by authors based on (Power Distance Index).

The characteristics of countries with low PDI are shown in Table 1. It is possible to find countries such as Austria (PDI = 11), Israel (PDI = 13), Denmark (PDI = 18), the Netherlands $(\mathrm{PDI}=22)$, Iceland (PDI $=30)$, Norway, Sweden $(\mathrm{PDI}=31)$, Finland $(\mathrm{PDI}=33)$ and some others. As can be seen from Figure 4, these countries have a rather high GDP per capita (average 50 thousands of GDP per capita in current US \$), as well as high human capital development indicators (from 0.861 in Estonia to 0.944 in Norway).

\section{Austria \\ Israel \\ Denmark \\ The Netherlands \\ Iceland \\ Sweden, Norway \\ Finland \\ Switzerland \\ Germany, Great Britain \\ New Zealand \\ USA, Estonia, Luxembourg}
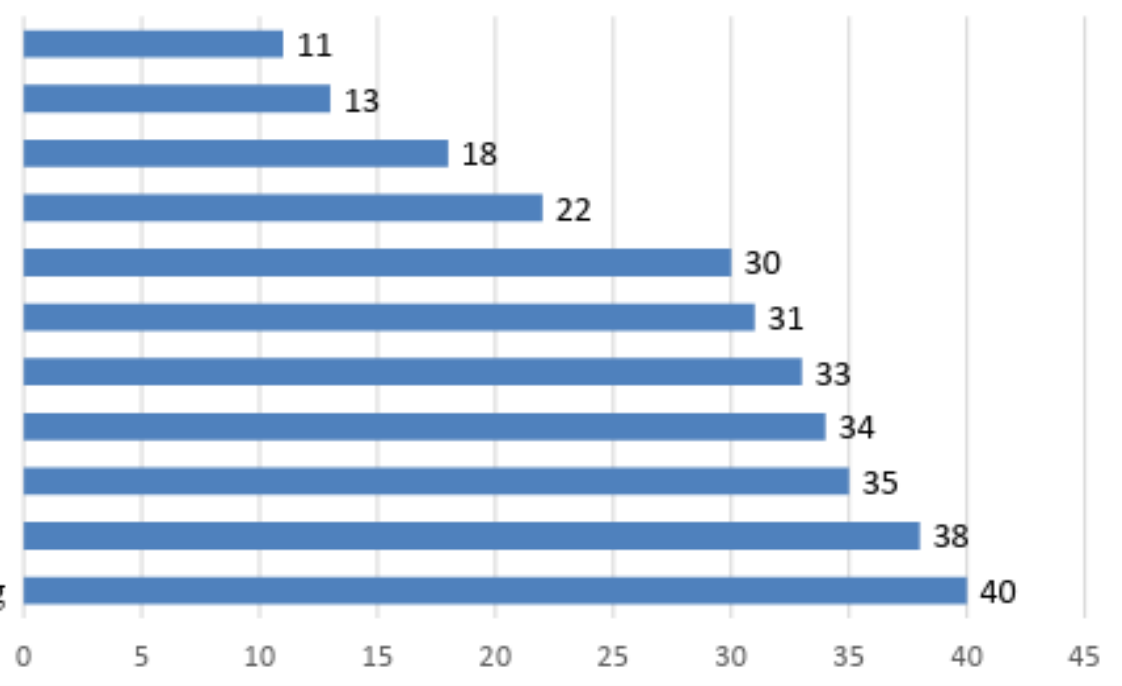

Figure 4. Examples of countries with low PDI Source: compiled by authors based on (Power Distance Index).

The influence of the power distance on the functioning of social institutions manifests itself in different ways. So, based on the analysis of "blackbox" data after numerous aviation disasters (Metscher, Smith, \& Alghamdi, 2009), scientists have posited that airplane management errors were due to the fact that the crew members did not dare to challenge the first pilot at a time when he allowed a fatal error during the flight. The power distance in the 
field of education is manifested in the fact that students do not dare to ask their teacher to explain information that they may not understand, for fear of a negative reaction, and teachers in such conditions are not inclined for self-development or professional development, which somehow reduces the overall demands of workers and students. Later, in universities, the high level of power between teachers and students only reinforces and emphasizes the gap in education levels between, for example, Sweden, Norway, Great Britain and Ukraine. The power distance, even in an established hierarchical system such as the army, can also sometimes be harmful. For example, in Israel in the 1990s there was a reform of the relationship between senior and junior officers, designed to demonstrate that the planning of operations is important to have alternative opinions, which can then be used to verify the course of events during the operation. In a broader, more generalized view, alternative ideas are a factor in the competition of ideas, which characterizes democracy as an open society (Popper, 1994). Due to this characterizations, autocracies and oligarchies are trying to narrow the information field in order to distort the competition of ideas and thereby impose a non-alternative to the status quo.

The high power distance not only helps to maintain inequalities in societies in which it is demonstrative, giving benefits and privileges only to some, at the expense of others, but also contributes to lowering the quality of public goods. Thus, M. Kohn's study, conducted in Italy and the United States, showed that the less accountable individuals (representatives of the socalled "working class") are prone to an authoritarian style of behavior both in the workplace and in the family, while representatives of middle class with a good level of education, seek to reduce the power gap both at work and in personal relationships (Kohn, 1969). Societies with high levels of quality education dominate horizontal ties but not vertical ones, where people are more actively engaged in dialogue and compromise, social cohesion, propensity to meritocracy, non-acceptance of corruption practices, high quality of provision of public goods, and social capital dominates over the administrative resource (freedom from political pressure).

We will try to estimate the relationship between the PDI and the level of crony-capitalism influence, which has been calculated since 2014. Thus, the magazine The Economist proposed a Crony-capitalism index - CCI (R. Sherma, A. Gandhi, M. Welton), which is based on the estimation of the wealth of world billionaires (estimates from Forbes magazine), which are related to industries where the dominant strategy is to find rent and personal interdependence relationships in one way or another. Since renting strategies are often used to indicate the contribution of land and capital as more profitable than other factors in competitive markets, rent-seeking sectors (Our Crony-capitalism Index) are recognized as sectors of the economy: national security and defense, casinos, infrastructure and pipelines, ports and airports, real estate and construction, oil and gas supplies, mining, iron and steel, coal and chemical industries, utilities and communications services, and deposit and investment banking services. The best forms of rent extraction are cartels, monopolies and lobbying, as well as corruption, clientism, and licensing. As it can be seen from the data in fig. 4, crony-capitalism is a problem in 15 out of 22 countries listed $(68 \%)$ (the 5 richest and 10 the most rapidly developing countries). The problem of Ukraine, as rightly noted by V. Melnichuk (2014), is that domestic oligarchs are not more similar to the Rockefellers, but to the large landowners of the Southern United States who opposed the abolition of slavery and in all ways inhibited the industrial revolution in the United States.

According to Figure 5, information can be found regarding the low proportion of sectors with domination of rent-seeking behavior in Germany, South Korea, France and the USA, along with extremely high percentages - in Malaysia, Ukraine, Russia, and the Philippines. It should be noted, however, that in Ukraine during 2014-2016 there was a significant decline in the total welfare of billionaires (from 14.8 to $7.8 \%$ of GDP), which corresponds to trends in the USA, Argentina, Mexico, Taiwan, and Poland. The CCI has also declined in these countries. In 
Ukraine, particularly, after the Revolution of Dignity, a large number of different groups of representatives from large capital began their struggle for rent. On the contrary, in Russia, India, Indonesia, Turkey, China, Thailand, the welfare of billionaires in percent of GDP increased with a corresponding increase of CCI (except India).
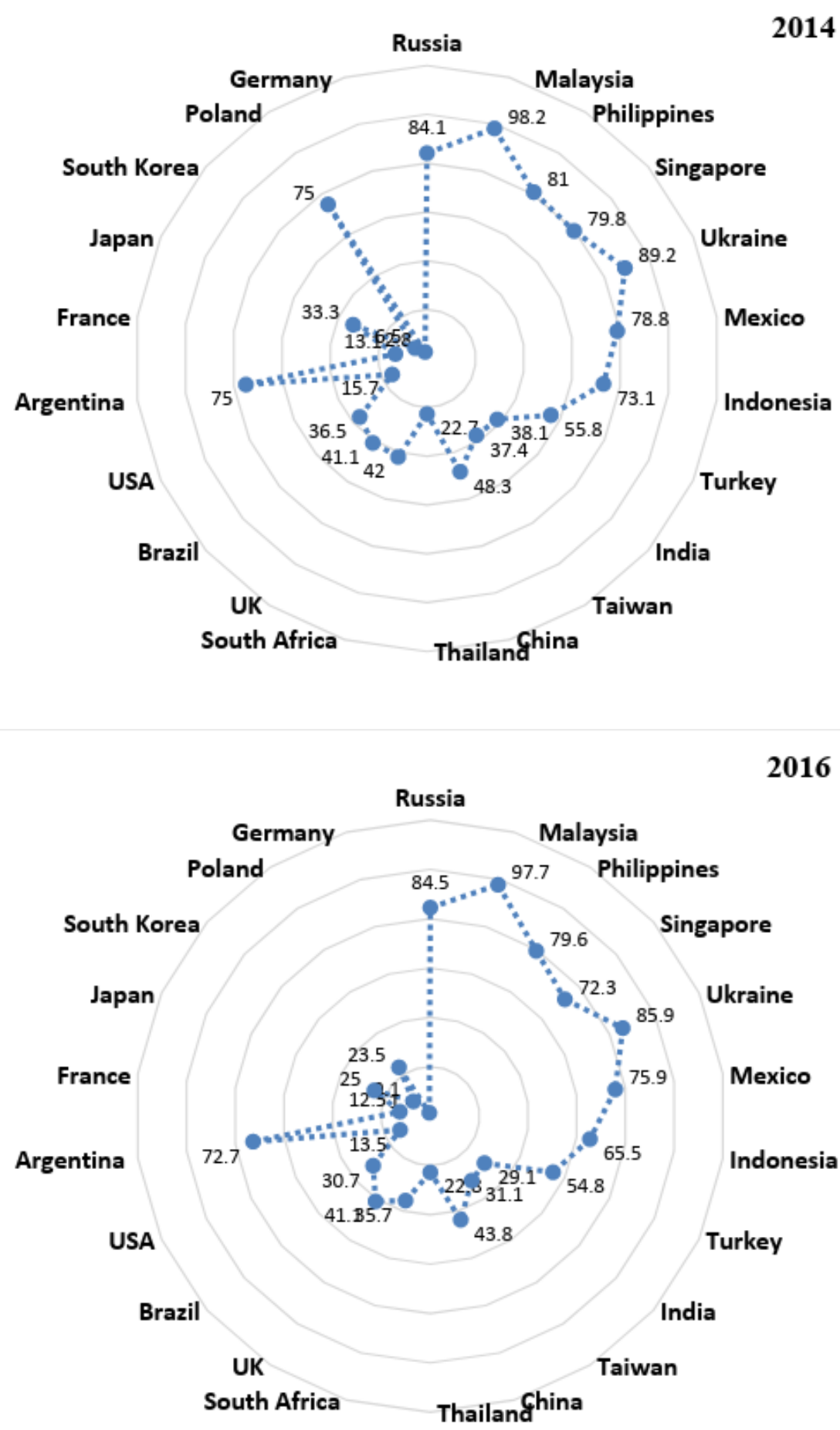

Figure 5. Share of crony-sectors with the domination of rent-seeking behavior in 2014 and $2016(\%)$

Source: own compilation based on (Comparing crony capitalism around the world). 
As discussed in (Kozyuk \& Dluhopolskyi, 2017), a regression analysis of the dependence of the power distance and crony-capitalism has shown that there is a clear and direct link between these indicators. The value of $\mathrm{R}^{2}$ varies within the range of $0.44-0.45$, depending on the function of approximation. Our analysis allows a confirmation of the hypothesis that cultural factors are important for explaining political and economic structure of the society. Thus, the PDI is directly connected with the index of crony-capitalism. Taking into account that the latter reflects the dominance of sectors with a high degree of hierarchy and dependence on the economy, it is safe to say that the attitude to power in society is an important precondition for the development of the institutional trajectory of the society. Tolerant attitudes toward hierarchy is a meta-factor of why certain societies take the form of interaction between government and business, the result of which is a clear anti-inclusiveness. Despite the fact that the distance to power can testify to tolerant attitude toward hierarchies, without which large industrial production is impossible, there is a particular risk. On the one hand, industrial structures are extremely sensitive to the extent to which the ability to accept subordination in a society is formed, since the transaction costs of the organization and the control over the functioning of the complexly organized vertical ties, which are the basis of the third technological way, are dependent on this. On the other hand, the existence of patterns of tolerance toward hierarchy enables oligarchy and property stratification, according to the criteria of the access to power / rent. Access to alternative institutional trajectories becomes extremely complicated when both situations in the country coincide. Third waves of innovation institutions (Burnam-Fink, 2011) become donors of oligarchy, reproducing the distance to power, and tolerance for hierarchies to reinforce the belief that it is with this type of relationship that at least a certain level of wellbeing is possible. In this way, an institutional "bad locked circle" is formed.

\section{Oligarchism versus ecologization}

An additional problem of the existence of crony sectors is that the oligarch's activity very often contradicts with sustainable development goals and the ecologization of the economy in the long run. As a rule, billionaires in the United States, whose activities are related to crony business, finance scientific research and movements aimed at discrediting environmental programs (Menotti, Barbara, Clarke, Shiva, \& Wen, 2011). Around the world, crony-business does not consider ecologization as a priority of social activity at all. This situation is understandable, since the interests of crony business and environmental movements are quite opposite, and the rent-orientation of the economy deforms and preserves social and economic development, reduces the innovation and competitiveness of economic systems, which contributes to the enrichment of the narrow circle of persons and the misery of the majority of the population in oligarchized societies (for example, Ukraine, Russia). It is also possible to foresee that the oligarch, who builds their wealth from the crony sector, will block environmental initiatives and changes in environmental legislation, which will cause more severe sanctions for violations and limit the construction of environmentally hazardous facilities. As to environmental taxation, we assume that in countries dominated by cronysectors, the level of environmental taxation is more likely to be less burdensome, or sanctions for violations less significant.

To test the hypothesis about an inverse relationship between the share of crony sectors and the level of environmental taxation, we use a regression analysis. As a set of statistical processes for estimating the relationships among variables, it helps us to demonstrate an indirect link between these indicators. Results of modelling in Figure 6 demonstrates the value of $\mathrm{R}^{2}=$ 0.15 . 


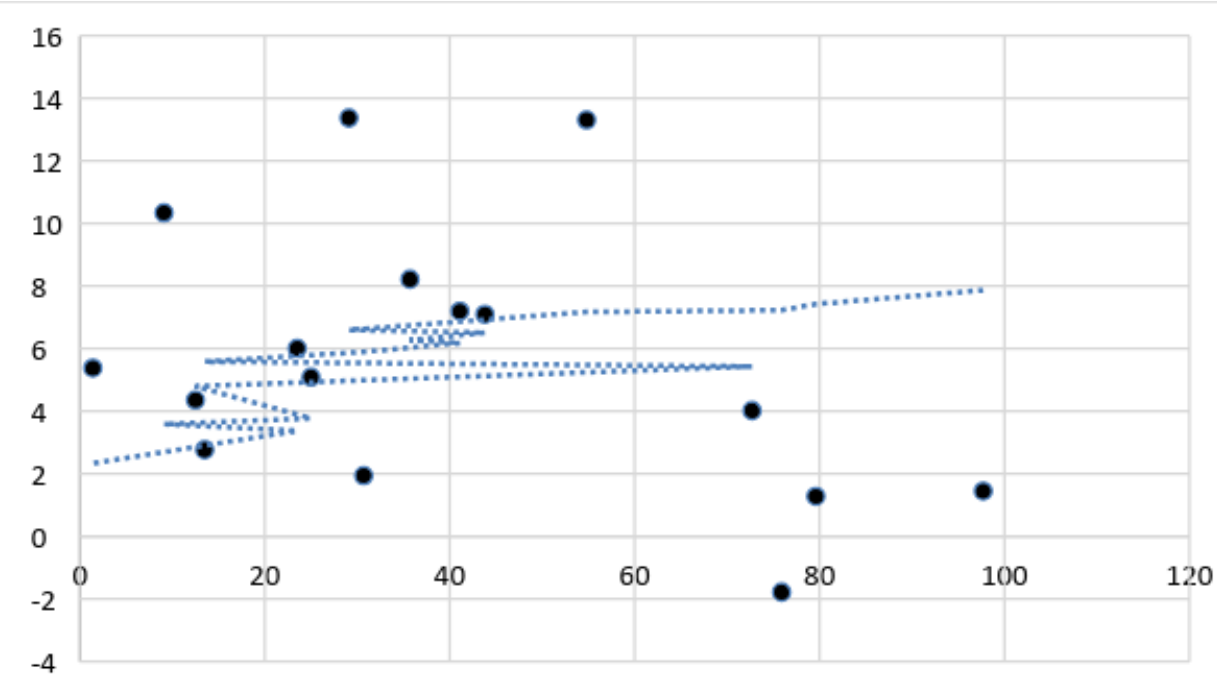

Figure 6. Correlation between environmentally related tax revenue (\% of total tax revenue) and share of sectors with the domination of rent-seeking behavior (\%)

Source: own calculations based on (Our Crony-capitalism Index; Environmental Performance Index).

But this opposition of the oligarchic clans to ecologization of welfare states in the long run, in our opinion, is doomed. This is not only due to the rapid development of renewable energy sector technologies, technologies in the growing demand for a high-quality environment in highly developed countries, but also for the reduction of exhaustive world resources and environmental disasters.

We can also analyze the connection between crony-sector development and environmental well-being sub-indexes from the Sustainable Society Index - SSI (Table 2). The Sustainable Society Foundation (SSF) introduced the Sustainable Society Index in 2006, to gauge the development of societies toward achieving sustainability. SSF recognizes a sustainable society as a society that (Sustainable Society Index): 1) meets the needs of the present generation, 2) does not compromise the resources of the future generation's necessities for their needs, and 3) believes that every human being is given the opportunity to progress in freedom within a well-balanced society and in harmony with the surroundings. The SSI consists of 21 indicators arranged under 7 categories and 3 dimensions (Table 2). The three cores of human well-being, environmental well-being and economic well-being are interdependent, where the dimension of human well-being manifests the fundamentals of human beings. Furthers environmental well-being represents the ecosystem where humans live. Economic well-being is defined by the essentials in which humans have the opportunity to able to do what they want.

From Table 3 and Figure 7, we can observe, that Ukraine had the most progress during 2006-2016 in environmental well-being and regress in human and economic well-being (especially in public debt and genuine savings indicators). During 2006-2016, Ukraine lost 3 positions in human well-being of SSI and 86 positions in economic well-being, but improved positions in environmental well-being ( +21 from 106th place in 2006 to 85th place in 2016). Ukraine's position in the basic needs indicator didn't change, where economic, transition and well-balanced society indicators decreased, and natural resources, climate \& energy and personal development \& health indicators increased (Figure 8). 
Table 2. Environmental Well-being sub-indexes from Sustainable Society Index (SSI)

\begin{tabular}{|c|c|c|c|}
\hline \multicolumn{2}{|r|}{ Natural Resources sub-index } & \multicolumn{2}{|r|}{ Climate \& Energy sub-index } \\
\hline$\sum_{\substack{0 \\
0}}^{\substack{0 \\
0}}$ & $\begin{array}{l}\text { Is expressed by two sub indicators: the } 10- \\
\text { years change of forest area and the size of } \\
\text { protected land areas in } \% \text { of the total country's } \\
\text { land area. }\end{array}$ & 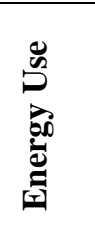 & $\begin{array}{l}\text { Energy use (TPES - Total Primary Energy } \\
\text { Supply) is defined as production }+ \text { imports - } \\
\text { exports } \pm \text { stock changes. }\end{array}$ \\
\hline 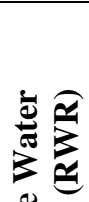 & $\begin{array}{l}\text { To monitor the sufficiency and the depletion } \\
\text { of fresh water resources, the indicator RWR } \\
\text { expresses the water consumption per year as a } \\
\text { percentage of total available renewable water } \\
\text { resources. This total includes internal and }\end{array}$ & 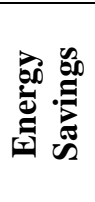 & $\begin{array}{l}\text { In many places and regions around the world } \\
\text { targets are set to reduce the consumption of } \\
\text { energy. The results of energy use reduction } \\
\text { plans and activities can be monitored by this } \\
\text { indicator. }\end{array}$ \\
\hline 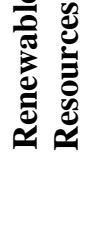 & $\begin{array}{l}\text { external (flowing in from neighboring } \\
\text { countries) water resources. }\end{array}$ & 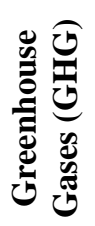 & $\begin{array}{l}\text { This indicator uses the common measure for } \\
\text { Emission of GHG: the amount of emitted CO2. }\end{array}$ \\
\hline 苍 & $\begin{array}{l}\text { As a proxy for consumption the Ecological } \\
\text { Footprint has been used minus the Carbon } \\
\text { Footprint. The latter is already included in the } \\
\text { SSI, by the indicator Emission of Greenhouse } \\
\text { Gases. }\end{array}$ & 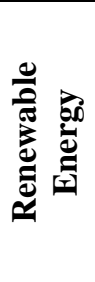 & $\begin{array}{l}\text { Consumption of renewable energy expresses the } \\
\text { share of energy produced by renewable sources } \\
\text { in \% of total energy (TPES). Renewable energy } \\
\text { includes hydro, geothermal, solar photovoltaic, } \\
\text { solar thermal, tide, wave, ocean, wind, solid } \\
\text { biomass, gases from biomass, liquid biomass } \\
\text { and renewable municipal waste. }\end{array}$ \\
\hline
\end{tabular}

Source: own compilation based on (Sustainable Society Index).

Table 3. Sustainable Society Index

\begin{tabular}{|c|c|c|c|c|c|}
\hline \multirow[t]{2}{*}{ Dimensions } & \multirow[t]{2}{*}{ Categories } & \multirow[t]{2}{*}{ Indicators } & \multicolumn{3}{|c|}{ Ukraine } \\
\hline & & & 2006 & 2016 & Progress \\
\hline \multirow{9}{*}{$\begin{array}{l}\text { Human Well- } \\
\text { being }\end{array}$} & \multirow{3}{*}{ Basic Needs } & Sufficient Food & 10,0 & 10,0 & 0,0 \\
\hline & & Sufficient Drink & 9,7 & 9,6 & $-0,1$ \\
\hline & & Safe Sanitation & 9,5 & 9,6 & 0,1 \\
\hline & \multirow{3}{*}{$\begin{array}{c}\text { Personal } \\
\text { Development } \\
\text { and Health }\end{array}$} & Healthy Life & 6,7 & 7,4 & 0,7 \\
\hline & & Education & 8,9 & 9,6 & 0,7 \\
\hline & & Gender Equality & 6,8 & 7,0 & 0,2 \\
\hline & \multirow{3}{*}{$\begin{array}{l}\text { Well-balanced } \\
\text { Society }\end{array}$} & Income Distribution & 8,2 & 9,7 & 1,5 \\
\hline & & Population Growth & 9,3 & 8,5 & $-0,9$ \\
\hline & & Good Governance & 3,8 & 3,4 & $-0,4$ \\
\hline \multirow{7}{*}{$\begin{array}{c}\text { Environmental } \\
\text { Well-being }\end{array}$} & \multirow{3}{*}{$\begin{array}{c}\text { Natural } \\
\text { Resources }\end{array}$} & Biodiversity & 3,7 & 3,7 & 0,0 \\
\hline & & Renewable Water Resources & 9,3 & 9,2 & $-0,1$ \\
\hline & & Consumption & 5,8 & 6,9 & 1,1 \\
\hline & \multirow{4}{*}{$\begin{array}{l}\text { Climate and } \\
\text { Energy }\end{array}$} & Energy Use & 3,9 & 5,3 & 1,4 \\
\hline & & Energy Savings & 2,2 & 9,8 & 7,7 \\
\hline & & Greenhouse Gases & 3,8 & 4,8 & 1,0 \\
\hline & & Renewable Energy & 1,0 & 1,0 & 0,0 \\
\hline \multirow{5}{*}{$\begin{array}{l}\text { Economic } \\
\text { Well-being }\end{array}$} & \multirow{2}{*}{ Transition } & Organic Farming & 2,2 & 2,9 & 0,7 \\
\hline & & Genuine Savings & 8,6 & 3,4 & $-5,2$ \\
\hline & \multirow{3}{*}{ Economy } & Gross Domestic Product & 4,0 & 4,2 & 0,3 \\
\hline & & Employment & 4,2 & 4,6 & 0,4 \\
\hline & & Public Debt & 9,6 & 1,0 & $-8,6$ \\
\hline
\end{tabular}

Source: own calculations based on (Sustainable Society Index). 


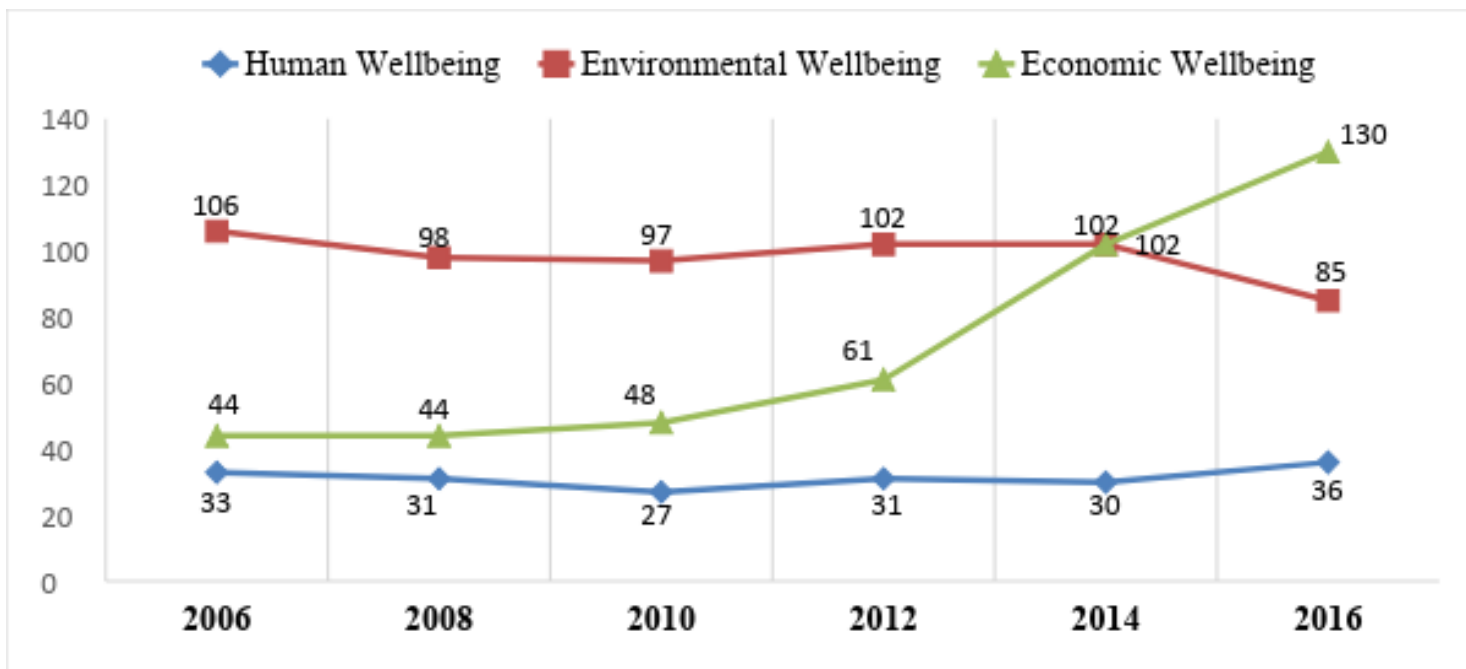

Figure 7. Positions of Ukraine in human, environmental and economic well-being during 2006-2016

Source: own calculations based on (Sustainable Society Index).

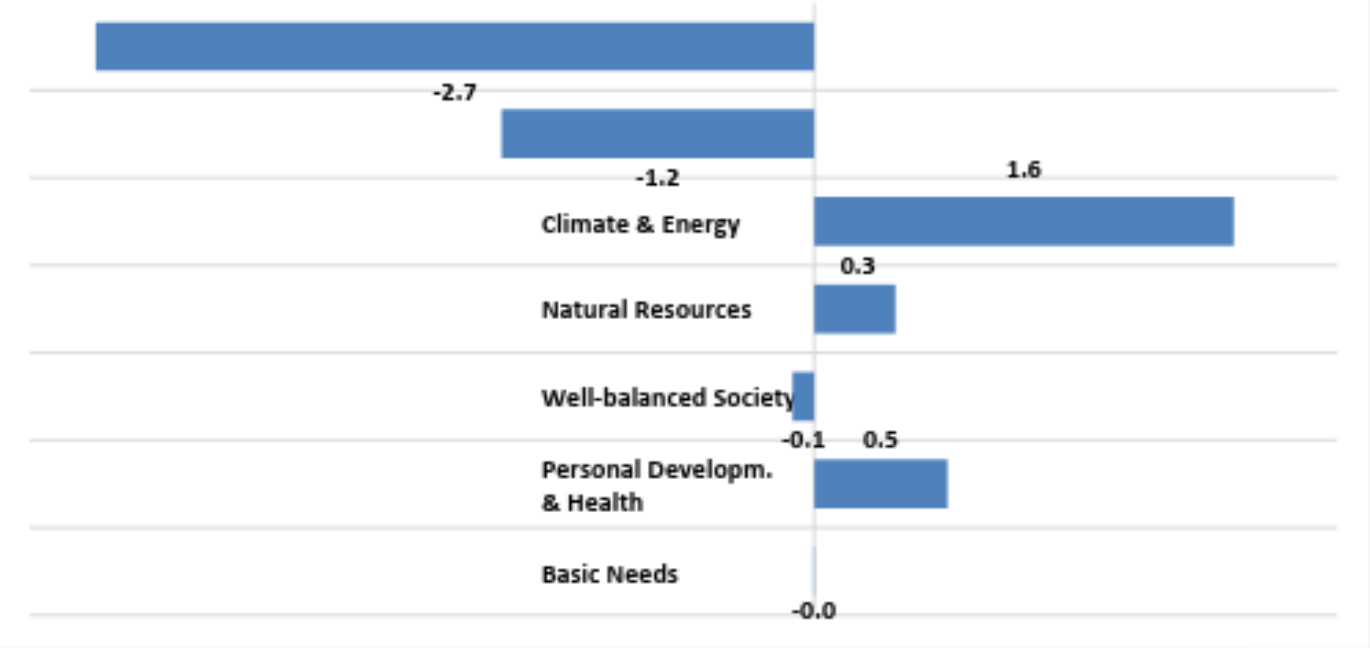

Figure 8. Progress Scores 2006-2016 of Ukraine

Source: own calculations based on (Sustainable Society Index).

Figure 9-10 display the regression between levels of crony-capitalism and two subindexes from environmental SSI: natural resources and climate \& energy. In both cases, the link between these indicators is direct but not strong. 


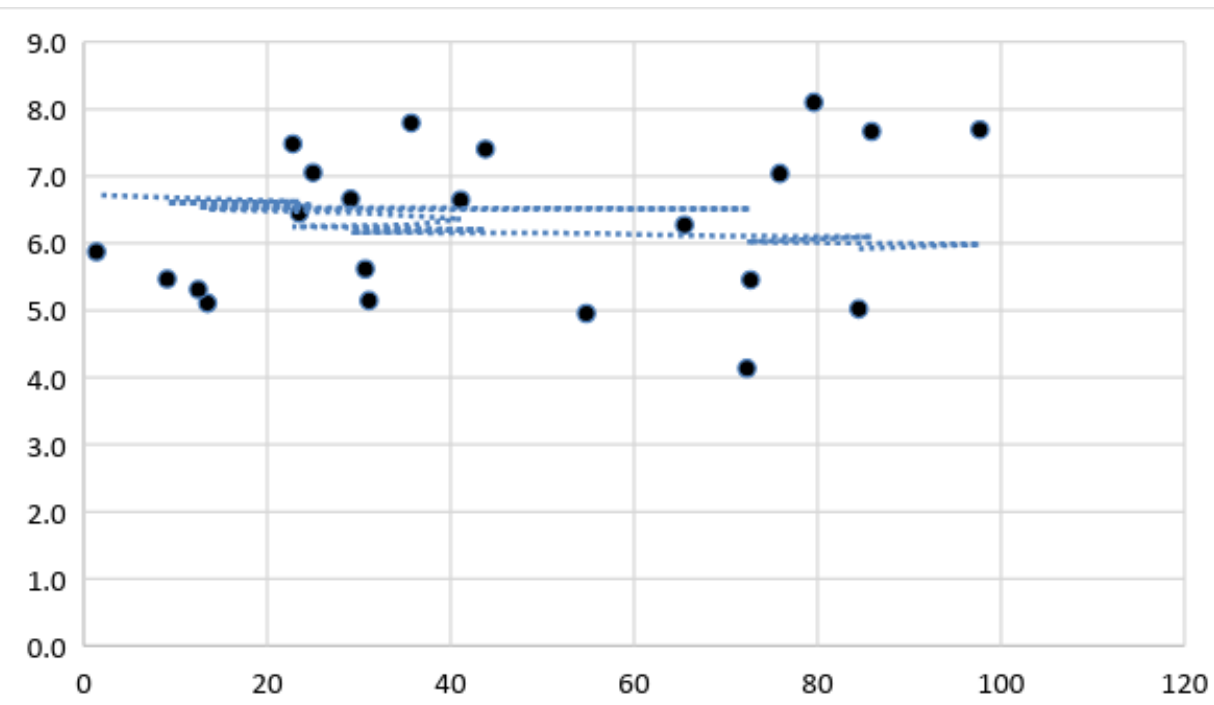

Figure 9. Correlation between Natural Resources sub-index from Environmental Well-being and share of sectors with the domination of rent-seeking behavior (\%)

Source: own calculations based on (Our Crony-capitalism Index; Environmental Performance Index).

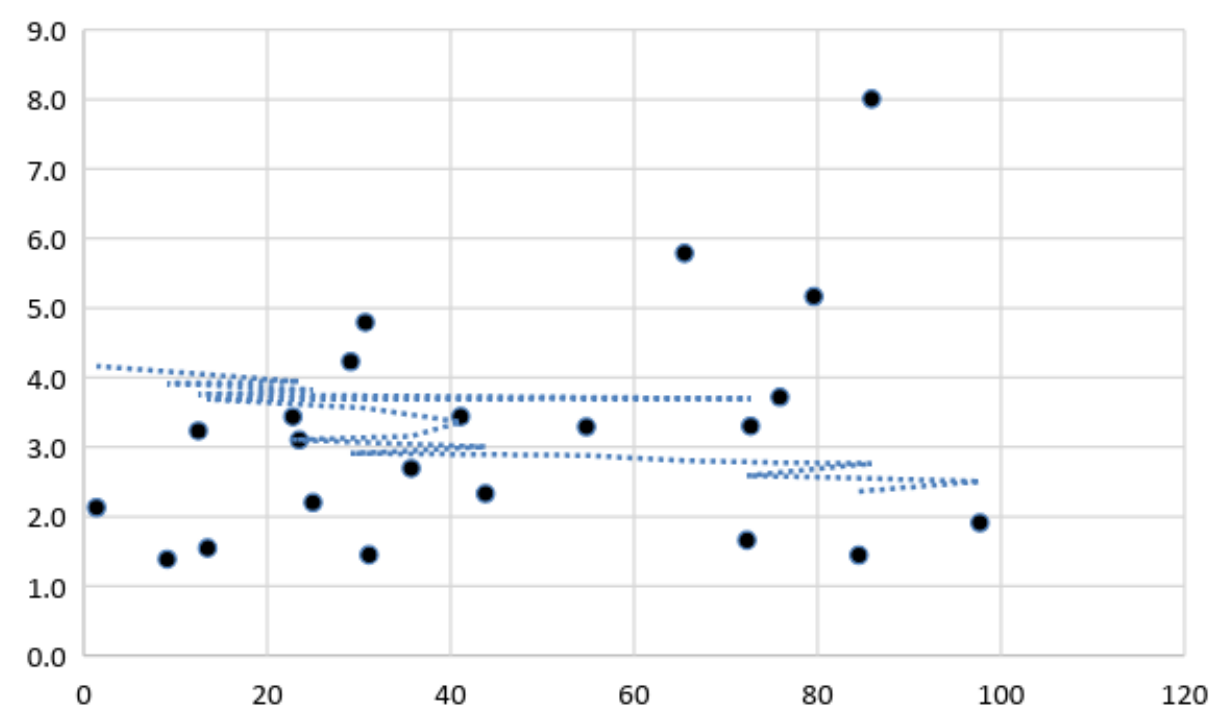

Figure 10. Correlation between Climate \& Energy sub-index from Environmental Well-being and share of sectors with the domination of rent-seeking behavior (\%)

Source: own calculations based on (Our Crony-capitalism Index; Environmental Performance Index).

In spite of oligarchical pressure on policymakers as choice architects in developing countries to not to develop strong ecological policies (in Nordic countries, for example), there are some ecological international initiatives which support governments around the world. Among them is the Global Green Growth Institute (GGGI), as a new international organization that was founded at the Rio+20 conference in 2012. GGGI works with developing and emerging countries to design and deliver programs and services that demonstrate new pathways to propoor economic growth. The institute provides Member Countries with the tools to help build 
institutional capacity and develop green growth policy, strengthen peer learning and knowledge sharing, and engage private investors and public donors (Global Green Growth Institute).

Strategic outcome targets of GGGI are:

- GHG reductions,

- green jobs,

- sustainable services,

- air quality,

- ecosystem services,

- enhanced adaptation to climate change.

Table 4 demonstrates the main green growth initiatives in some developing economies by GGGI during last 5 years.

Table 4. Green model of economic growth activities by GGGI

\begin{tabular}{|c|c|c|}
\hline № & Country & Initiatives \\
\hline 1. & Ethiopia & $\begin{array}{l}\text { GGGI and the Government of Ethiopia aim to support the development of an effective, government } \\
\text { owned Climate Resilient Green Economy system that leads to the development of a strategic } \\
\text { program of bankable investments, which maps out in relation to industry, to transport, to energy, } \\
\text { cities development, agriculture, continued capitalization of the CRGE Facility to fund those } \\
\text { investments and an effective and strategic monitoring and evaluation framework. Additionally, the } \\
\text { aim is to facilitate key systemic transformations in the economy and generate innovative ideas } \\
\text { towards a climate resilient green economy. }\end{array}$ \\
\hline 2. & Cambodia & $\begin{array}{l}\text { GGGI's objective in Cambodia is to support green city planning by raising awareness of green } \\
\text { growth concepts and instruments as well as to assist in the development of bankable green city } \\
\text { projects that result in climate change resilience and improved livelihoods for Cambodia's urban } \\
\text { poor. }\end{array}$ \\
\hline 3. & Colombia & $\begin{array}{l}\text { GGGI objective in Colombia is to support the country's economic growth objectives while } \\
\text { implementing inclusive and environmentally sustainable growth principles into its long term } \\
\text { economic planning frameworks. Recognizing the importance of its forest resources in reducing } \\
\text { GHG emissions to help meet Colombia's NDC and SDG targets, GGGI is supporting the } \\
\text { government in achieving its goal of zero net deforestation by } 2020 \text { through the Amazon Vision } \\
\text { program. The Amazon Vision Fund is a payment for performance scheme, whereby people living } \\
\text { in forests and farmers are rewarded for leaving forest standing and for preserving the ecosystems. } \\
\text { Main donors, including Germany and Norway, are coming in with } \$ 45 \text { million to actually make } \\
\text { sure that fund can operate. }\end{array}$ \\
\hline 4. & Ir & $\begin{array}{l}\text { GGGI's role and objective in Indonesia is to assist the government in delivering green growth by } \\
\text { driving investment and designing green projects with social, environmental and economic benefits } \\
\text { for the people of Indonesia. The analysis shows that if the government of a province East } \\
\text { Kalimantan were not to invest in coal but to invest instead in decentralized solar power and in } \\
\text { biomass, they could actually save themselves a lot of money. GGGI is now engaged with the } \\
\text { private sector to see how it's possible to find investors to deliver on that strategy. }\end{array}$ \\
\hline 5. & Rwanda & $\begin{array}{l}\text { GGGI's objective in Rwanda is to provide technical support to the National Fund for Environment } \\
\text { and Climate Change (FONERWA) facility, to support the development planning of } 6 \text { Green } \\
\text { Secondary Cities, and to help government with reform of the electricity sector based on public- } \\
\text { private partnership model. }\end{array}$ \\
\hline 6. & Jordan & $\begin{array}{l}\text { GGGI's objective in Jordan is to support the government in its implementation of the National } \\
\text { Green Growth Plan. GGGI is working on a green grow strategy, which focuses partly on the } \\
\text { tourism sector (hotel companies with that part of private sector). }\end{array}$ \\
\hline 7. & Costa Rica & $\begin{array}{l}\text { GGGI's objective in Costa Rica is to achieve Costa Rica's national commitment to Carbon } \\
\text { Neutrality by } 2021 \text { with total net emissions comparable to } 2005 \text {. Costa Rica today is succeeding in } \\
\text { becoming completely reliant on renewables in terms of electricity supply. }\end{array}$ \\
\hline 8. & Philip & $\begin{array}{l}\text { GGGI's objective in Philippines is to support the mainstreaming of Green Growth into the } \\
\text { country's Development Planning, operationalize the People's Survival Fund and to scale-up the } \\
\text { Climate Resilient Green Growth Planning (CRGG) program at the provincial level. About } 95 \% \text { of } \\
\text { the economy in the Philippines is extremely vulnerable to the impacts of climate change, and }\end{array}$ \\
\hline
\end{tabular}




\begin{tabular}{|c|c|}
\hline & $\begin{array}{l}\text { extreme weather events. GGGI works with the government of the Philippines to develop a model } \\
\text { to climate proof municipalities. }\end{array}$ \\
\hline 9. China & $\begin{array}{l}\text { GGGI's objective in China is supporting the government with its aim to green South-South } \\
\text { Cooperation (SSC) and One Belt One Road (OBOR) initiatives, including overseas investments, } \\
\text { and introduce a green growth approach in Chinese provinces. China is beginning to address } \\
\text { industrial policy because of big issues around air quality and the cost of poor air quality to the } \\
\text { economy. Today, poor air quality is costing China about } 12 \% \text { of its GDP because a lot of people } \\
\text { are dying earlier because of poor air quality or spending a lot of time in hospitals. }\end{array}$ \\
\hline 10. India & $\begin{array}{l}\text { GGGI supports in India the design of an innovative debt fund to unlock the decentralized renewable } \\
\text { energy market by making available capital to enterprises for capital expenditure and working } \\
\text { capital requirements, and at the same time to help develop an ecosystem of investors, lenders, and } \\
\text { development institutions. }\end{array}$ \\
\hline 11. $\quad$ Peru & $\begin{array}{l}\text { GGGI's objective in Peru is to develop the enabling policy framework for green procurement } \\
\text { jointly with the Ministry of Economy and Finance, as part of the implementation phase of the } \\
\text { National Eco-efficiency Strategy as well as to develop action plans for various sectors that align } \\
\text { its National Green Growth Strategy and other sectoral policies. }\end{array}$ \\
\hline 12. Mongolia & $\begin{array}{l}\text { GGGI's program in Mongolia directly supports the government's green development targets of } \\
20 \% \text { renewably generated electricity, } 20 \% \text { building heat loss reduction, and } 2 \% \text { of GDP for green } \\
\text { investment by } 2020 \text {. }\end{array}$ \\
\hline
\end{tabular}

Source: own compilation based on (Global Green Growth Institute).

\section{Conclusion}

The development of technologies enables new forms of organizational interactions that do not require rigid hierarchies. That is why oligarchic structures often hinder technological progress and ecologization, since the latter "wipes out" the social and electoral basis needed for their self-reproduction. That is why blocking free entrepreneurship, risk-oriented technologies, ecologization, low taxation of creative sectors, and cultivating a bad business climate are becoming the dominant instruments of the state economic policy controlled by the oligarchical clans. Overcoming cultural constraints beyond the tolerance of hierarchies that reproduce oligarchism may not be successful if the focus is on opposing technological progress and distance to power. Most important will be the creation of conditions for alternative forms of social interactions and business organizational modalities that are generated by a combination of access to new technologies and market self-regulation. The main instruments of economic policy should be inclusive access to knowledge, minimizing barriers to entrepreneurship, improving institutional quality and lowering the tax rates (especially for ecological products).

Cultural factors have a direct correlation to the economy, especially in increasing the probability of crony-sector domination. Together with the lack of democratic control and weak institutions, they result in economic oligarchization. A direct link between PDI and the cronycapitalism index is confirmed empirically. Also, an indirect link between environmental tax revenues and the crony-capitalism index is confirmed. The value of tolerance to hierarchy is significant while explaining the institutional trajectory of country's development. In the case where crony sectors are hampering technological progress and inclusive growth, structural reforms can be complicated due to the lack of public request to overcome hierarchies. The rigor of such a system limits development, which means that the struggle with hierarchical, oligarchical structures should not be at the level of cultivating alternative values, but at the level of blurring social and electoral crony-sector support. Fiscal incentives for entrepreneurial development, promotion of start-ups, quality of institutions, and investments in human capital and green industries are, albeit stereotyped, but necessary to overcome the negative enchantment of the link between oligarchism and tolerance of hierarchical values. 
Policymakers should use ecological policy more efficiently, applying different approaches to responsible waste management, efficient energy use, and development of new technologies. This means using taxes, subsidies and fees in strategic and systematic ways. The global ecological policy can be unified for all countries, but regional approaches and instruments should be developed according to specific income levels and abilities of technological absorption of every country.

\section{Acknowledgement}

The research was conducted within the Project 0117U000412 "Ecologization in a new paradigm of welfare state", 2017-2019.

\section{References}

Acemoglu, D. (2008). Oligarchic versus democratic societies. Journal of the European Economic Association, 6(1), 1-44. https://doi.org/10.1162/JEEA.2008.6.1.1.

Acemoglu, D., \& Robinson, J.A. (2015). Economic origins of dictatorship and democracy. Moscow.

Acemoglu, D., \& Robinson, J.A. (2016). Why nations fail? The origins of power, prosperity and poverty. Kyiv.

Aslund, A. (2005). Comparative oligarchy: Russia, Ukraine and the United States. Studies \& Analyses, 296, 1-17.

Burnam-Fink, M. (2011). Waves of Innovation: "Konratiev Waves" Help Explain What Carries Our Economy Forward over Generations. Retrieved from https://scienceprogress.org/2011/05.

Comparing crony capitalism around the world, IMF. Access via internet: www.economist.com. Corruption Perceptions Index 2016. Retrieved from http://www.transparency.org/cpi2015.

de Soto, H. (2017). The mystery of capital. Why capitalism triumphs in the West and fails everywhere else?. Kyiv.

Dluhopolskyi, O.V. (2015). The welfare state and quality of life: Nordic countries experience and Ukrainian reality. Social-economic problems and state, 2(13), 294-302. Retrieved from http://sepd.tntu.edu.ua/images/stories/pdf/2015/15doviru.pdf.

Environmental Performance Index (2016). Palisades, NY: NASA Socioeconomic Data and Applications Center (SEDAC). Access via internet: https://doi.org/10.7927/H4FX77CS.

Evans, P. (1995). Embedded autonomy: states and industrial transformation. Princeton: Princeton University Press.

Geert Hofstede and his theory of culture changes: overview information (2011). Retrieved from http://news.telelangue.com/ru/2011/10/hofstede-cultural-theory.

Global Green Growth Institute. Access via internet: http://gggi.org.

Haber, S. (2003). It wasn't all Prebisch's fault: the political economy of Latin American industrialization. Working Paper, Stanford University.

Hellman, J.S. (1998). Winners take all: the politics of partial reform in Post-communist transitions. World Politics, 50, 203-234.

Helman, V.Y. (2010). The logic of "private capitalism": big oil, big business and big policy in Russia. Economy and Institutes, 5, 172-191.

Hofstede, G. (2001). Culture's consequences: comparing values, behaviors, institutions and organizations across nations. Thousand Oaks CA: Sage Publications.

Hofstede, G., Hofstede, G. J., \& Minkov, M. (2010). Cultures and organizations: software of the mind. McGraw-Hill. 
Kang, D.C. (2002). Crony Capitalism: Corruption and Development in South Korea and the Philippines. Cambridge: Cambridge University Press.

Kharlamova, H. (2015). Ecological economics versus economic(al) ecology. Bulletin of Taras Shevchenko National University of Kyiv. Economics, 174(9), 83-98. doi: http://dx.doi.org/10.17721/1728-2667.2015/174-9/14.

Kohn, M.L. (1969). Class and conformity: a study in values. The Dorsey Press, Homewood, IL.

Konchyn, V., \& Horban, Y. (2016). Economic point of bifurcation for Ukrainian oligarchic state in the stationary bandit model. Retrieved from http://mpra.ub.unimuenchen.de/70953.

Kozyuk, V.V. (2014). Quality of institutions and deviation of exchange rates from PPP: implications for economic growth. Journal of European Economy, 13(1), 3-19.

Kozyuk, V.V. (2016). Financial development, foreign exchange reserves and political regimes in commodity economies. Economic Theory, 3, 82-102.

Kozyuk, V.V. (2017). NBU tomorrow: From the "embraces" of oligarchic octopus - to the printing press? Economical truth, 17 May. Retrieved from https://www.epravda.com.ua/rus/columns.

Kozyuk, V.V., \& Dluhopolskyi, O.V. (2017). Power distance and value orientations influence on oligarchism and crony-sectors development in modern economic systems. Bulletin of Taras Shevchenko National University of Kyiv. Economics, 193(4), 30-37. doi: https://doi.org/10.17721/1728-2667.2017/193-4/5.

Kozyuk, V.V., \& Shimanska, O.P. (2013). The political economy of oligarchic economics. Herald of TNEU, 3, 97-104.

Kuznets, S. (1955). Economic growth and income inequality. American Economic Review, 49, $1-28$

Lopes Harsia, A.I. (2017). Oligarchic policy in Latin America. Retrieved from https://voxukraine.org/2017.

McCormick, K., Richter, J.L., \& Pantzar, M. (2015). Greening the Economy Compendium. Lund: Lund University.

McGuire, M., \& Olson, M. (1996). The economics of autocracy and majority rule: the invisible hand and the use of force. Journal of Economic Literature, 34, 72-96.

Melnichuk, V.G. Oligarchs are tearing down the country. Retrieved from https://argumentua.com.

Menotti, V., Barbara, J.S., Clarke, T., Shiva, V., \& Wen, D. (2011). Outing the Oligarchy. Billionaires who benefit from Today's Climate Crisis: A Special Report by the International Forum on Globalization (IFG), 149 p.

Metscher, D.S., Smith, M., \& Alghamdi, A. (2009). Multi-cultural factors in the crew resource management environment: promoting aviation safety for airline operations. Journal of Aviation / Aerospace Education \& Research, 18(2). Retrieved from http://commons.erau.edu/jaaer/voll8/iss2/6.

North, D.C., Wallis, J.J., \& Weingast, B.R. (2009). Violence and social orders: a conceptual framework for interpreting recorded human history. N.Y.: Cambridge University Press.

Our Crony-capitalism Index: the party winds down. Retrieved from https://www.economist.com/news/international.

Pei, M. (2016). China's Crony Capitalism: The Dynamics of Regime Decay. Harvard University Press.

People and corruption: Europe and Central Asia 2016. Retrieved from http://www.transparency.org.

Popper, K. (1994). The open society and its enemies. Vol. I, Kyiv, 444 p. 
Popper, K. (1994). The open society and its enemies. Vol. II, Kyiv, 494 p.

Porter, M.E., \& van der Linde, C. (1995). Toward a New Conception of the EnvironmentCompetitiveness Relationship. Journal of Economic Perspectives, 9(4), 97-118.

Power Distance Index. Geert Hofstede cultural dimensions. Clearly cultural: making sense of cross cultural communication. Retrieved from http://www.clearlycultural.com.

Sorj, B., \& Martuccelli, D. (2014). The Latin American challenge: social cohesion and democracy.

Soskin, O. (2014). The model of economy and business-environment development: the logic of euro integration changes. Economy of enterprises: theory and practice: Materials of international science and practice conference (10.10.2014), Kyiv, 43-48.

Sustainable Society Index (2016). Retrieved from http://www.ssfindex.com/ssi/indicatordescription.

The World Bank (2016). Retrieved from https://data.worldbank.org/indicator.

United Nations Environment Program - UNEP (2011). Towards a green Economy: Pathways to Sustainable Development and Poverty Eradication. Retrieved from www.unep.org/greeneconomy.

Volhonsky, B. (2008). Rise and fall of "tigers" and "dragons". Retrieved from http://www.russ.ru/pole.

Wagner, M. (2003). The Porter Hypothesis Revisited: A Literature Review of Theoretical Models and Empirical Tests. Center for Sustainability Management.

Zingales, L. (2012). A Capitalism for the People: Recapturing the Lost Genius of American Prosperity. New York: Basic Books. 